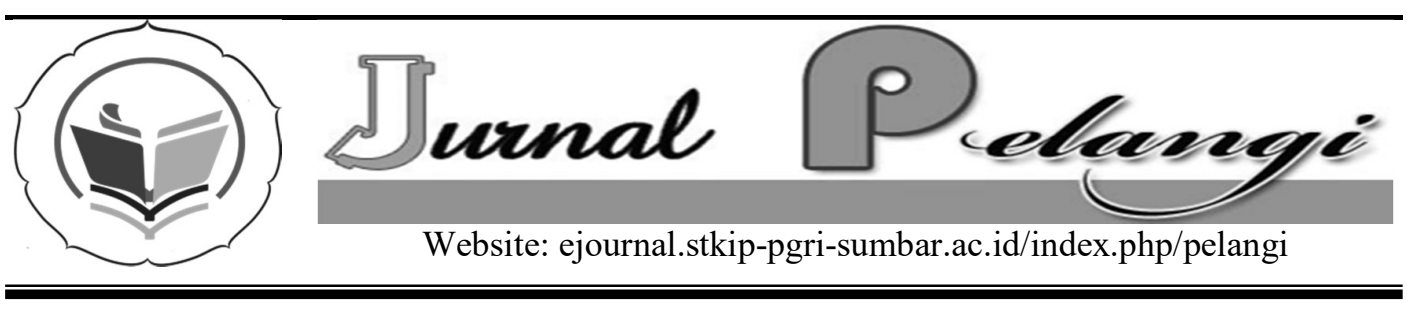

\title{
EFEKTIVITAS METODE STRATAGEM TERHADAP AKTIVITAS MAHASISWA
}

\author{
Radhya Yusri \\ STKIP PGRI Sumatera Barat \\ radhyayusri@stkip-pgri-sumbar.ac.id
}

\section{INFO ARTIKEL}

Diterima:

1 Agustus 2016

Direview:

27 September 2016

Disetujui:

28 Desember 2016

Kata Kunci:

Aktivitas belajar, Efektivitas, Metode stratagem, Pemahaman Konsep

\begin{tabular}{l}
\hline Keywords: \\
\hline Activity, Efectivity, \\
Stratagem Methods, \\
Understanding of \\
Concept
\end{tabular}

ISSN: 2085-1057

\begin{abstract}
Abstrak
Penelitian ini bertujuan untuk mengetahui apakah metode stratagem efektif dalam meningkatkan aktivitas belajar mahasiswa dalam pembelajaran matematika. Rancangan penelitian yang digunakan adalah One Group Pretest-Posttest Design. Populasi pada penelitian ini adalah seluruh mahasiswa Program Studi Pendidikan Matematika yang sedang mengambil Mata Kuliah Geometri Ruang yang terdiri dari 4 sesi yaitu sesi A sampai sesi D. Sedangkan subjek penelitian adalah mahasiswa Sesi D sebanyak 26 orang yang diambil secara Purposive dengan pertimbangan kebanyakan mahasiswanya kurang aktif dan kurang berpartisipasi dalam proses pembelajaran. Hasil penelitian menunjukkan bahwa rata-rata persentase aktivitas mahasiswa dalam pembelajaran adalah $82 \%$ dari tiga pertemuan. Rata-rata persentase aktivitas mahasiswa pada pertemuan pertama $76 \%$, pertemuan kedua $82 \%$ dan pertemuan ketiga $87 \%$. Hal ini menggambarkan terjadi peningkatan aktivitas mahasiswa dalam proses pembelajaran dengan menggunakan metode stratagem. Sehingga disimpulkan bahwa metode stratagem efektif dalam meningkatkan aktivitas belajar mahasiswa dalam proses pembelajaran matematika.
\end{abstract}

\begin{tabular}{l} 
Abstract \\
\hline This study aims to determine whether the stratagem method \\
was effective in improving student learning activities in \\
learning mathematics. The research design used is One Group \\
Pretest-Posttest Design. Population in this research is all \\
student of Mathematics Education Study Program which is \\
taking Spectrum Geometry Course consisting of 4 session that \\
is session A until session D. While subject of research is \\
student of Session D as many as 26 people taken Purposive \\
with consideration most students are less active and less \\
participate in the learning process. The results showed that the \\
\hline
\end{tabular}


average percentage of student activity in learning was $82 \%$ of the three meetings. Average percentage of student activity at first meeting $76 \%$, second meeting $82 \%$ and third meeting $87 \%$. This illustrates the increase in student activity in the learning process by using stratagem method. So it is concluded that stratagem method is effective in improving student learning activities in the process of learning mathematics

\section{PENDAHULUAN}

Matematika merupakan ilmu pengetahuan yang sangat penting dalam ilmu-ilmu lainnya. Tidak ada satupun disiplin ilmu yang dalam perkembangannya bisa benar-benar terlepas dari penggunaan matematika. Pada hakekatnya belajar matematika adalah berfikir dan berbuat atau mengerjakan matematika. Berbuat untuk mengubah tingkah laku, jadi belajar adalah melakukan suatu kegiatan. Tidak ada belajar kalau tidak ada aktivitas. Itulah sebabnya, aktivitas merupakan hal yang sangat penting dalam interaksi belajar mengajar. Tanpa adanya aktivitas mahasiswa, maka tujuan pembelajaran tidak akan tercapai dengan baik. Belajar matematika tidak hanya menuntut mahasiswa untuk mendapatkan nilai yang tinggi saja, tetapi juga menuntut akan terbentuknya pribadi yang berakhlak mulia, kritis, kreatif, mandiri dan bertanggung jawab. Sehingga dengan kepribadian yang demikian setiap mahasiswa akan terlibat dan berpartisipasi dalam mencapai tujuan pembelajaran dan proses pembelajaran yang dilakukan akan menjadi lebih efektif.

Keefektivan dalam pembelajaran berhubungan dengan sejauh mana mahasiswa dapat mencapai tujuan pembelajaran yang telah dirancang atau keberhasilan mahasiswa dalam mencapai tujuan pembelajaran (Sanjaya, 2008). Dengan demikian, disimpulkan bahwa efektif adalah keberhasilan terhadap suatu usaha atau tindakan yang dilakukan untuk mencapai suatu tujuan tertentu yang telah direncanakan. Apabila hasilnya tidak jauh dari perencanaan maka dapat dikatakan cukup efektif, dan sebaliknya apabila hasilnya masih jauh dari perencanaan maka dikatakan belum atau kurang efektif. Pembelajaran dikatakan efektif apabila dalam proses pembelajaran setiap elemen berfungsi secara keseluruhan, mahasiswa merasa senang dan puas dengan hasil pembelajaran, membawa kesan yang baik bagi mahasiswa dan yang terpenting adalah dapat meningkatkan kompetensi mahasiswa.

Hasil observasi menunjukkan bahwa proses pembelajaran yang dilakukan masih bersifat teacher centered yaitu dengan memberikan penjelasan tentang materi kepada mahasiswa tanpa adanya keterlibatan mahasiswa secara langsung dalam menemukan atau mencari sendiri konsep materi yang dipelajari. Mahasiswa hanya menerima begitu saja apa yang diberikan dosen, kurang berani mencoba dalam sebuah kegiatan untuk menemukan jawaban dari pertanyaan yang diberikan. Sehingga mengakibatkan suasana pembelajaran monoton dan tidak menyenangkan. Aktivitas mahasiswa hanya mendengar, memperhatikan dan mencatat yang dijelaskan dosen, hanya beberapa mahasiswa yang ikut berpartisipasi dalam proses pembelajaran.

Dosen harus selalu berupaya menciptakan pembelajaran yang mampu mengaktifkan mahasiswa agar berani mencoba untuk mendapatkan apa yang 
mereka cari (konsep), dan memperoleh apa yang mereka butuhkan serta membuat suasana belajar menjadi menyenangkan yaitu dengan melibatkan mahasiswa secara langsung dalam proses pembelajaran. Oleh karena itu, di dalam proses pembelajaran dosen harus memiliki metode agar mahasiswa dapat belajar efektif dan efisien serta dapat mencapai tujuan pembelajaran yang diharapkan (Darmayasa, 2011: 44-51). Salah satu cara yang dilakukan adalah dengan menerapkan metode stratagem. Metode permainan stratagem merupakan suatu aktifitas yang menyenangkan, ringan dan bersifat kompetitif (Romlah, 1989). "Bermain adalah cara belajar yang menyenangkan, karena dengan bermain bisa belajar sesuatu tanpa menyadarinya", apa yang dipelajari itu disimpan dalam pikiran sehingga akan dipadukan menjadi suatu kesatuan dengan pengalaman lain yang kadang-kadang tanpa disadari. Metode Stratagem dalam pembelajaran kooperatif dapat meningkatkan motivasi belajar matematika Mahasiswa (Wahyuni, 2012). Proses pembelajaran dengan menggunakan metode Stratagem pada hakikatnya adalah belajar sambil bermain untuk memecahkan suatu permasalahan tanpa ada ketegangan dalam dirinya, dengan mengungkapkan pendapat, mengajukan pertanyaan, serta dapat memahami konsep-konsep materi dalam proses pembelajaran.

Berdasarkan uraian di atas maka tujuan penelitian ini adalah untuk meningkatkan dan menumbuhkembangkan aktivitas belajar mahasiswa melalui penerapan metode stratagem pada mata kuliah Geometri Ruang.

\section{METODE PENELITIAN}

Jenis penelitian ini adalah penelitian pra-eksperimen. Penelitian ini menggunakan satu kelas sampel yaitu kelas eksperimen yang diberikan perlakuan metode Stratagem.

Penelitian dilakukan di STKIP PGRI Sumatera Barat pada mahasiswa Program Studi Pendidikan Matematika yang mengambil mata kuliah Geometri Ruang. Subjek penelitian ini adalah mahasiswa yang terdapat pada kelas Sesi D sebanyak 26 orang yang diambil secara Purposive dengan pertimbangan pada umumnya mahasiswanya kurang aktif dan kurang berpartisipasi dalam proses perkulihan Geometri Ruang. Sehingga mereka mengalami kesulitan dalam menyelesaikan permasalahan yang diberikan oleh dosen.

Instrumen yang digunakan adalah lembar observasi. Lembar observasi ini bertujuan untuk melihat aktivitas mahasiswa selama proses perkuliahan dengan metode stratagem. Observasi dilakukan setiap pertemuan dan hasilnya dicatat pada lembar observasi. Lembar observasi aktivitas mahasiswa disusun berdasarkan pada keterampilan mahasiswa yang disesuaikan dengan metode stratagem, yaitu: 1) memperhatikan dosen menjelaskan materi, 2) memberikan pendapat terkait pertanyaan yang diberikan dosen, 3) mendengarkan pertanyaan yang di bacakan saat permainan, 4) menyalin jawaban soal yang mereka bahas, 5) ikut serta berdiskusi bersama teman kelompok dalam permainan, 6) mengerjakan soal-soal dalam permainan, dan 8) semangat dalam mengikuti permainan.

Teknik analisis data yang digunakan dalam penelitian ini adalah dengan menghitung persentase aktivitas mahasiswa yang terdapat pada lembar observasi mahasiswa selama proses perkuliahan. Data yang diperoleh melalui lembar observasi, akan dihitung persentase aktivitasnya. Setelah diperoleh persentase aktivitas Mahasiswa, kemudian dilihat kriteria 
aktivitas berdasarkan yang dikemukakan oleh Mudjiono (2006: 125).

\begin{aligned} \hline $1 \%<\mathrm{P} \leq 25 \% & :$ Sedikit sekali \\ $25 \%<\mathrm{P} \leq 50 \% & :$ Sedikit \\ $50 \%<\mathrm{P} \leq 75 \% & :$ Banyak \\ $75 \%<\mathrm{P} \leq 100 \% & :$ Banyak sekali \end{aligned}

\section{HASIL DAN PEMBAHASAN}

Data aktivitas mahasiswa diperoleh dari lembar aktivitas. Pengamatan dilakukan dengan mencatat dan mendaftar banyaknya mahasiswa yang melakukan aktivitas sesuai dengan indikator yang terdapat pada lembar aktivitas. Hasil pengamatan aktivitas mahasiswa selama tiga kali pertemuan disajikan dalam Tabel 1.

Data persentase aktivitas mahasiswa diatas menunjukkan bahwa Aktivitas mahasiswa setiap pertemuan mengalami peningkatan yang baik. Hasil analisis observasi aktivitas mahasiswa pada pertemuan $\mathrm{I}=76 \%$, pertemuan II $=82 \%$, pertemuan III $=87 \%$, persentase aktivitas mahasiswa cendrung meningkat di setiap pertemuan. Ratarata persentase aktivitas mahasiswa selama tiga kali pertemuan adalah $82 \%$. Ini berarti, metode Stratagem dalam pembelajaran matematika khususnya pada mata kuliah Geometri Ruang efektif dalam meningkatkan aktivitas mahasiswa.
Data persentase aktivitas mahasiswa diatas menunjukkan bahwa Aktivitas mahasiswa setiap pertemuan mengalami peningkatan yang baik. Hasil analisis observasi aktivitas mahasiswa pada pertemuan $\mathrm{I}=76 \%$, pertemuan II $=82 \%$, pertemuan III $=87 \%$, persentase aktivitas mahasiswa cendrung meningkat di setiap pertemuan. Ratarata persentase aktivitas mahasiswa selama tiga kali pertemuan adalah $82 \%$. Ini berarti, metode Stratagem dalam pembelajaran matematika khususnya pada mata kuliah Geometri Ruang efektif dalam meningkatkan aktivitas mahasiswa.

Berdasarkan deskripsi data terhadap aktivitas belajar mahasiswa pada mata kuliah Geometri Ruang dengan metode stratagem maka dibahas sebagai berikut:

a. Tetap berada dalam kelompok selama mengerjakan latihan

Aktivitas mahasiswa yang tetap berada dalam kelompok selama mengerjakan latihan dari pertemuan pertama sampai pertemuan ke tiga selalu mengalami peningkatan. Hal ini terjadi karena pada saat pembelajaran berlangsung, mahasiswa diberikan suatu informasi oleh dosen, bahwa bagi mahasiswa yang tetap berada dalam kegiatan kelompok sampai jam pelajaran habis akan diberikan suatu nilai tambah.

Tabel 1. Deskripsi Persentase Aktivitas Mahasiswa

\begin{tabular}{cccc}
\hline Aktivitas Mahasiswa & I & Pertemuan & III \\
Persentase perolehan & $76 \%$ & II & $87 \%$ \\
\hline
\end{tabular}

Sumber: Olahan Analisis Aktivitas Mahasiswa 


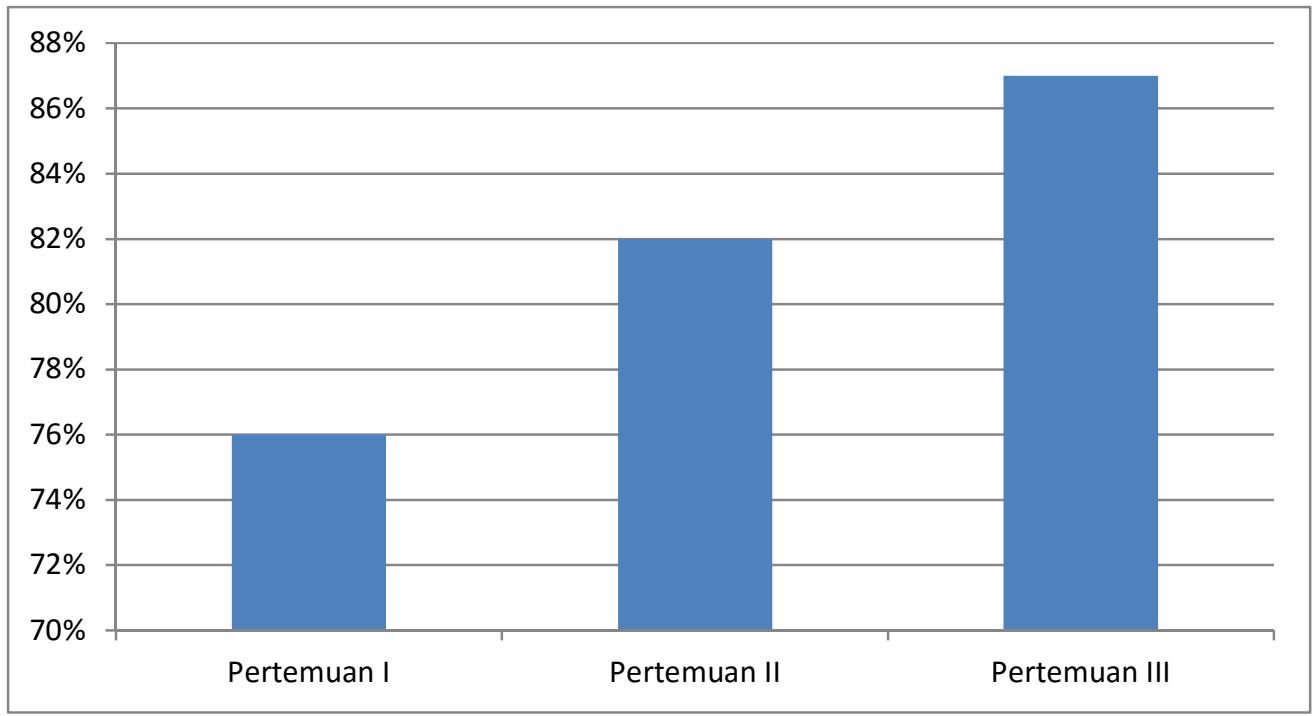

\section{Gambar. Analisis Aktivitas Mahasiswa}

b. Partisipasi mahasiswa dalam kegiatan kelompok

Partisipasi mahasiswa dalam kegiatan kelompok pada tiap pertemuan cenderung meningkat. Hal ini terjadi karena sebelumnya mahasiswa sudah mengetahui bahwa dosen memberikan nilai dengan memberikan tanda centang atau tanda bintang dalam suatu lembaran bagi mahasiswa yang selalu aktif atau ikut serta dalam kegiatan kelompoknya.

c. Menyampaikan ide terhadap penyelesaian masalah dalam kelompok

Berdasarkan pengamatan yang telah dilakukan saat pertemuan pertama terdapat sepuluh orang yang menyampaikan ide terhadap penyelesaian masalah yang terjadi dalam kelompok, Adapun masalah yang terjadi yaitu adanya jawaban yang berbeda dalam kelompok, ataupun memberikan solusi terhadap masalah yang ditemukan. Pada umumnya mahasiswa yang memberikan ide dalam kelompok adalah mahasiswa yang berprestasi dalam kelasnya ataupun Mahasiswa yang mengerti dengan matematika, khususnya tentang materi yang sedang dipelajari.

d. Menanggapi

pertanyaan/permasalahan kelompok

Pada pertemuan pertama, persentase aktivitas ini sangat sedikit sekali. Hal ini terjadi karena mahasiswa hanya sibuk dengan menggambar grafik yang terdapat didalam bahan ajar, mahasiswa hanya terfokus pada bahan ajar yang dimilikinya masingmasing, sehingga kegiatan dalam kelompok kurang terlihat. Namun, pada pertemuan berikutnya aktivitas menanggapi pertanyaan/ permasalahan didalam kelompok sudah mulai terlihat, hal ini terjadi karena latihan yang diberikan sifatnya penyelesaian langsung. Sehingga memunculkan banyak pertanyaan, karena pertanyaan yang akan diselesaikan tersebut berbeda dengan contoh soal yang diterangkan saat pembelajaran. Kebanyakan pertanyaan tersebut muncul dari Mahasiswa yang kurang mengerti dengan matematika.

e. Bertanggung jawab terhadap tugas Pada tiap pertemuan persentase mahasiswa yang bertanggung jawab terhadap tugas umumnya banyak 
sekali. Hal ini terjadi karena setiap tugas ataupun latihan yang diberikan itu sangat mempengaruhi nilai mahasiswa. Semakin rajin mahasiswa mengerjakan tugas, maka semakin bertambah pula nilai yang diperoleh mahasiswa, sehingga motivasi Mahasiswa untuk itu meningkat dan mahasiswa merasa khawatir tidak mengerjakannya.

f. Bertanya kepada dosen

Aktivitas mahasiswa bertanya kepada dosen dapat dikategorikan sedikit. Ketika dosen menjelaskan materi, mahasiswa cenderung mencatat dan menjawab pertanyaan dosen. Setelah diberikan kestigaan bertanya, maka barulah mahasiswa bertanya kepada dosen, namun hanya sedikit Mahasiswa yang bertanya. Pada pertemuan kedua persentase aktivitas naik karena indikator materinya tidak terlalu sulit, sehingga mahasiswa dapat memahami materi dengan cepat. Pertemuan ketiga juga terjadi peningkatan. Pada pertemuan tersebut, penjelasan yang diberikan tidak banyak sehingga pertanyaan yang muncul pun sedikit.

g. Tepat waktu dalam menyelesaikan tugas

Pada aktivitas tepat waktu dalam mengerjakan tugas persentasenya turun pada pertemuan ketiga, karena waktu yang diberikan dosen terlalu sedikit bagi mahasiswa, dan tugas yang harus diselesaikan itu banyak dan kurang dipahami. Disamping itu, pertanyaan yang diselesaikan tersebut merupakan pertanyaan baru. Semangat dalam mengikuti permainan.

\section{PENUTUP}

Berdasarkan hasil penelitian dapat disimpulkan bahwa Metode Stratagem dalam pembelajaran matematika efektif dalam meningkatkan aktivitas
Mahasiswa hingga mencapai persentase $70 \%$.

\section{UCAPAN TERIMA KASIH}

Terbitnya tulisan ini tidak terlepas dari bantuan berbagai pihak, untuk itu penulis ucapkan terima kasih kepada UP3M STKIP PGRI Sumatera Barat sebagai penyandang dana dan pengelola jurnal Pelangi yang telah memberikan saran dan revisi dalam penulisan artikel ini.

\section{DAFTAR PUSTAKA}

Arikunto, Suharsimi. 2006. Prosedur Penelitian. Jakarta : PT. Adi Mahasatya

Hamalik, Omaer. 2005. Kurikulum dan Pembelajaran , Bumi Aksara , Jakarta

Irianto, Agus. 2006. Statistik Konsep Dasar dan Aplikasinya. Jakarta : Kencana Perdana Media

Jiang, F \& McComas (2015). Effect of Inquiry Teaching on Student Science Score Achievement and Attitude: Evidence of Propensity From Score Analysis of PISA Data. International Journal of Science Education, 37(3), 554-576.

Lufri. 2007. Kiat Memahami Metodologi dan Melakukan Penelitian. Padang : UNP Press

Margared E. Bell Gredler. 1991. Belajar dan Membelajarkan. Jakarta: CV Rajawali.

Muliyardi. 2002. Strategi Pembelajaran Matematika. Padang : Dosen Jurusan Matematika FMIPA UNP 
Prawironegoro, Pratiknyo. 1985. Evaluasi Hasil Belajar Khusus Analisis Soal Untuk Bidang Studi Matematika. Jakarta: CV Fortuna

Ratumanan, Tanwey Gerson. 2002. Belajar dan Pembelajaran. Surabaya: UNESA university press

Sameto.2003.Belajar dan Faktor-Faktor yang Mempengaruhinya .Jakarta: PT Rineka Cipta

Sanjaya, Wina. 2008. Kurikulum dan Pmbelajaran. Jakarta: Kencana Pranada Media Group
Sardiman. 2001. Interaksi dan Motivasi Belajar Mengajar. Jakarta : PT Raja Grafindo Perssada

Soetopo, Hendyat, dan Wasty Soemanto. 1991. Pembinaan dan Pengembangan Kurikulum. Jakarta: Bumi Aksara.

Krismanto. 2003. Teknik, Model, dan Strategi dalam Pembelajaran Matematika. Yogyakarta 